\title{
Timing of Dense-Core Vesicle Exocytosis Depends on the Facilitation L-Type Ca Channel in Adrenal Chromaffin Cells
}

\author{
Abdeladim Elhamdani, ${ }^{1}$ Zhuan Zhou, ${ }^{2}$ and Cristina R. Artalejo ${ }^{1}$ \\ ${ }^{1}$ Department of Pharmacology, Wayne State University, School of Medicine, Detroit, Michigan 48201, and ${ }^{2}$ Department of \\ Biology, University of Science and Technology of China, Hefei, Anhui 230027, China
}

\begin{abstract}
Secretion from dense-core vesicles is reputedly much slower than that from typical synaptic vesicles, possibly because of noncolocalization of $\mathrm{Ca}$ channels and release sites. We reinvestigated this question by measuring the kinetics of catecholamine release in chromaffin cells from calf and adult bovines. Amperometric recording from calf chromaffin cells stimulated by action potentials exhibited two latencies of secretion that depended on both the frequency of stimulation and the pathway of $\mathrm{Ca}$ entry. Short-latency responses $(<25 \mathrm{msec}$ delay; "strongly coupled") appeared at low $(0.25$ and $1 \mathrm{~Hz})$ and high $(7$ $\mathrm{Hz}$ ) frequencies and were entirely dependent on recruitment of "facilitation" L-type $\mathrm{Ca}$ channels as revealed by nisoldipine blockade. Long-latency responses (>25 msec delay; "weakly coupled") were more apparent at higher frequencies $(7 \mathrm{~Hz})$ and were substantially reduced by toxins that blocked $\mathrm{N}$ - and P-type Ca channels. Ca current recordings revealed that adult
\end{abstract}

bovine chromaffin cells lack facilitation channels; virtually all secretion was weakly coupled in these cells. The mean delay of the strongly coupled signal was $\sim 3 \mathrm{msec}$ after the peak of the action potential (at $24^{\circ} \mathrm{C}$ ), indicating that dense-core vesicles can exhibit a rate of exocytosis approaching that occurring in neurons. Although other explanations are possible, these results are consistent with the idea that facilitation $\mathrm{Ca}$ channels are colocalized with release sites in calf chromaffin cells. Calculations based on a model incorporating this assumption suggest that these channels must be within $13 \mathrm{~nm}$ of secretory sites to account for such rapid exocytosis.

Key words: dense-core vesicles exocytosis; facilitation L-type $\mathrm{Ca}$ channels; adrenal chromaffin cells; colocalization of $\mathrm{Ca}$ channels and release sites; amperometric recording; catecholamine release
Neurotransmitter release from presynaptic nerve terminals is extremely rapid. The time from spike invasion of the presynaptic terminal to postsynaptic response may be $<1 \mathrm{msec}$ at some synapses (Barrett and Stevens, 1972; Llinas et al., 1981; Sabatini and Regehr, 1996). An important element contributing to the speed of this event is the colocalization of $\mathrm{Ca}$ channels and release sites at the active zone, minimizing the distance over which $\mathrm{Ca}$ ions must diff use to reach the divalent cation receptors for secretion. In the nervous system, such colocalization has been shown on a number of levels: direct morphological correlation between sites of Ca influx and secretion (Robitaille, 1990; Haydon et al., 1994) as well as biochemical association of specific Ca channel subtypes with protein components of the exocytotic apparatus (Sheng et al., 1996).

Secretion by dense-core vesicles in both neurons and neuroendocrine cells is generally considered to be much slower than that found at typical excitatory neuronal synapses (Almers, 1990; Martin, 1994). At synapses that contain both small synaptic vesicles and peptide-containing large dense-core vesicles, higherfrequency stimulation is often necessary to evoke peptide secretion than that required for small neurotransmitters (Whim and

Received March 10, 1998; revised May 7, 1998; accepted June 8, 1998.

This work was supported by grants from National Institutes of Health (C.R.A.), National Science Foundation (C.R.A.) Grant DGICYT PM95-0035 (C.R.A.), and Human Science Frontiers Foundation (A.E.). C.R.A. is a Sloan Fellow. We thank Yanfang Hu for expert preparation of ProCFE. We thank Drs. T. F. J. Thomas, Martin, E. Neher, H. C. Palfrey, and O. D. Uchitel for their helpful criticisms on this manuscript.

Correspondence should be addressed to Dr. Cristina R. Artalejo, Department of Pharmacology, Wayne State University, School of Medicine, 540 E. Canfield Avenue, Detroit, MI 48202.

Copyright $(\odot 1998$ Society for Neuroscience $\quad 0270-6474 / 98 / 186230-11 \$ 05.00 / 0$
Lloyd, 1989). The slow rates of secretion found for some cells containing dense-core vesicles have been attributed in part to spatial separation between Ca channels and sites of transmitter/ hormone release, although there may be other differences in the secretory machinery (Martin, 1994). For example, in adult bovine chromaffin cells, detection of secreted catecholamine by extracellular amperometric recording revealed a lag of 20-100 msec after stimulation (Chow et al., 1992, 1994, 1996). Such a lag may reflect poor colocalization of $\mathrm{Ca}$ channels with the secretory apparatus in this cell type (Chow et al., 1994, 1996; Zhou and Misler, 1995; Klingauf and Neher, 1997).

Despite these findings, there are indications that the relationship between $\mathrm{Ca}$ channels and secretion is nonrandom in several cell types containing dense-core vesicles. Insulin secretion is preferentially coupled to L-type Ca channel activity in $\beta$-cells, suggesting that these channels are closer to release sites than other types of Ca channel (Bokvist et al., 1995). Rapid exocytosis in mouse adrenal slices was also attributed to close association between $\mathrm{Ca}$ channels and the secretory apparatus (Moser and Neher, 1997). Moreover, we previously demonstrated selective coupling between a particular type of $\mathrm{Ca}$ channel and secretion in calf adrenal chromaffin (AC) cells (Artalejo et al., 1994). Using measurements of membrane capacitance as an estimate of exocytosis, we found that $\mathrm{Ca}$ flowing through facilitation L-type $\mathrm{Ca}$ channels was approximately five times more efficiently coupled to secretion than $\mathrm{Ca}$ entering via $\mathrm{N}$ - and P-type $\mathrm{Ca}$ channels (Artalejo et al., 1994). These results suggest that the facilitation L-type $\mathrm{Ca}$ channel is close to the secretory apparatus in these cells, but the limitations of capacitance recording precluded precise resolution of rapid stimulus-secretion coupling kinetics. 
To resolve this problem we have analyzed the kinetics of catecholamine secretion from cells derived from young and adult bovines using more sensitive amperometric techniques (Wightman et al., 1991; Chow et al., 1992). We determined the contribution of different components of the Ca current to the secretory responses in these two cell types. We found that a major component of secretion in calf AC cells is strongly coupled to the facilitation L-type Ca channel with average latencies of $<5 \mathrm{msec}$. Although other explanations are possible, these results can be accounted for if facilitation $\mathrm{Ca}$ channels are in very close physical apposition $(<15 \mathrm{~nm})$ to release sites in calf AC cells. By similar reasoning, most $\mathrm{Ca}$ channels are remote from release sites in adult AC cells.

\section{MATERIALS AND METHODS}

\section{Cell culture}

Both calf (average age, 10-12 weeks) and adult (age, $>2$ years) chromaffin cells were prepared by digestion of bovine adrenal glands obtained from local slaughterhouses. Cells were purified and cultured using previously described methods (Artalejo et al., 1991a). Cells plated at a density of $3 \times 10^{5}$ cells on collagen-coated 35 -mm-diameter dishes were used in all studies, within 1 week of plating.

\section{Electrophysiology}

Conventional whole-cell recording. Our patch-clamp techniques have been published previously (Artalejo et al., 1991a,b, 1992a); Axopatch 200 B (Axon Instruments, Foster City, CA) was used as the patch-clamp amplifier for these experiments. All experiments were performed at room temperature $\left(24^{\circ} \mathrm{C}\right)$. The standard patch-pipette solution contained (in mM): cesium glutamate 110 , Cs-EGTA 0.1, HEPES $40, \mathrm{MgCl}_{2} 5$, ATP 2, GTP 0.35, pH 7.2, with $\mathrm{CsOH}$ (nucleotides were added fresh to the stock salt solution just before the experiment). The external solution consisted of (in mM): $\mathrm{CaCl}_{2}$ 2, TEA-Cl 150, HEPES 10, glucose $10, \mathrm{MgCl}_{2}$, and $1 \mu \mathrm{M}$ tetrodotoxin, $\mathrm{pH}$ 7.2. When necessary, the following $\mathrm{Ca}$ channel antagonists were added to the external solution to suppress individual $\mathrm{Ca}$ current components (Artalejo et al., 1994): nisoldipine (final $1 \mu \mathrm{M}$ ), $\omega$-conotoxin-GVIA $(\omega$-CgTx) (final $500 \mathrm{nM})$, or $\omega$-agatoxin-IVA $(\omega$ Aga-Tx) (10 nM). In most experiments a solution containing the drugs dissolved in the external solution was applied directly to the cells via narrow-bore capillary tubing placed within $50 \mathrm{~mm}$ of the cell surface. Perfusion rates were computer-controlled, and complete bath exchange occurred in 100-200 msec. To assess the effects of "action potential-like" stimuli, actual current clamp records were used as templates for voltageclamp command pulses (McCobb and Beam, 1991). Currents were sampled at a frequency of $20 \mathrm{kHz}$.

Current-clamp recording. To evoke action potentials (APs), cells maintained at -70 to $-90 \mathrm{mV}$, through application of a holding current of -1 to $-4 \mathrm{pA}$, were stimulated by depolarizing currents $(+10$ to $+20 \mathrm{pA})$ of 20 msec. The eight-pole Bessel filter was set to a corner frequency of 2 $\mathrm{kHz}$ for $\mathrm{V}_{\mathrm{m}}$ recording and then sampled at $5 \mathrm{kHz}$. The pipette solution contained (in mM): potassium glutamate 100, K-EGTA 0.1, $\mathrm{NaCl} 12$, HEPES 30, $\mathrm{MgCl}_{2}$ 5, ATP 2, GTP 0.35, pH 7.2, with KOH. The external solution consisted of (in mM): $\mathrm{NaCl} \mathrm{140,} \mathrm{glucose} \mathrm{10,} \mathrm{HEPES} 10, \mathrm{MgCl}_{2}$

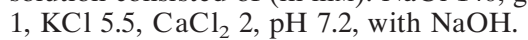

\section{Carbon-fiber amperometry for catecholamine detection}

Highly sensitive low-noise polypropylene-insulated carbon-fiber electrodes (ProCFEs) (Zhou and Misler, 1996) were used for electrochemical monitoring of quantal release of catecholamines from single AC cells as described previously (Wightman et al., 1991; Chow et al., 1992). Briefly, a 7-mm-diameter carbon fiber (Amoco Performance Products, Greenville, SC) was inserted into a polypropylene pipette (Continental Lab Products). The tip was then heated and pulled with a homemade CFE puller. The ProCFE was prepared for recording by inserting it into a micromanipulator and cutting the tip with a microscissor. To obtain electrical contact between the carbon fiber and the $\mathrm{Ag}$ wire input to the head stage of the amplifier, the shank of the ProCFE was back-filled with mercury. Each ProCFE was then used in a maximum of one to three cells to ensure the highest possible sensitivity. The tip of the electrode was closely apposed to the cell surface to minimize the diffusion distance from release sites. The amperometric current $\left(I_{\mathrm{amp}}\right)$, generated by oxi- dation of catecholamines at the exposed tip of the CFE, was measured using an Axopatch 200A amplifier, operated in the voltage-clamp mode at a holding potential of $+780 \mathrm{mV}$. Amperometric signals were low-passfiltered at $1 \mathrm{kHz}$ and then sampled at $2 \mathrm{kHz}$ by an Axobasic system. The data were collected and then analyzed by computer using IGOR software (WaveMetrics, Lake Oswego, OR). Latencies (defined as the time from the peak of the AP to the beginning of the current spike) were analyzed using latency histograms (Chow et al., 1992). The beginning of the current spike was located where the leading edge of the transient [which includes the "foot" signal when present (Chow et al., 1992; Zhou et al., 1996)] exceeded the baseline current by two times the SD of the baseline noise level. Only amperometric events having 50-90\% rise time faster than $3 \mathrm{msec}$ were selected for these histograms. Measurements are given as mean \pm SEM.

\section{RESULTS}

\section{Action potential waveforms recruit facilitation $\mathrm{Ca}$ channels in calf but not in adult AC cells}

The physiological stimulus for secretion in AC cells is the neurotransmitter acetylcholine $(\mathrm{ACh})$ released synaptically from splanchnic nerve terminals onto individual AC cells. ACh depolarizes AC cells, giving rise to trains of APs (Douglas et al., 1967) that evoke secretion (Kidokoro and Ritchie, 1980). To ascertain whether such stimulus trains can recruit facilitation $\mathrm{Ca}$ currents in chromaffin cells, we recorded APs in current-clamp mode and then played them back as voltage-clamp commands [AP waveforms (APWs)]. As shown in Figure 1, trains of APWs at either 1 or $7 \mathrm{~Hz}$ were able to recruit an extra component of inward $\mathrm{Ca}$ current in calf (10-12 weeks old) chromaffin cells that was completely blocked by nisoldipine $(1 \mu \mathrm{M})$. Although $7 \mathrm{~Hz}$ stimulation exerted a more rapid effect, additional $1 \mathrm{~Hz}$ trains eventually led to maximal activation of facilitation current. These results indicate that physiologically relevant stimulation of calf chromaffin cells activates facilitation L-type channels and confirms our previous results with square-wave depolarization (Artalejo et al., 1991a, 1992b). Nisoldipine has no effect on Ca current in naive cells (i.e., not subject to large predepolarizations or repetitive depolarizations in the physiological range), suggesting that calf AC cells lack a "standard" L-type Ca current. As described previously (Artalejo et al., 1994), the nondihydropyridinesensitive Ca current, comprising $\mathrm{N}$ - and P-type components, was completely suppressed by the combination of $\omega$-conotoxin and $\omega$-agatoxin (500 and $10 \mathrm{nM}$, respectively).

When a similar APW train paradigm was applied to AC cells derived from adult animals ( $>2$ years old), no additional $\mathrm{Ca}$ current was observed at either 1 or $7 \mathrm{~Hz}$, indicating that facilitation $\mathrm{Ca}$ channels are absent from these cells. However, a component of $\mathrm{Ca}$ current was inhibited by nisoldipine (Fig. $1 \mathrm{~B}$, right panel), indicating that adult bovine chromaffin cells do have a "standard" (nonfacilitated) L-type Ca current. These results are summarized in Figure 2. Facilitation $\mathrm{Ca}$ channels can also be recruited by stimuli that raise cAMP levels in calf AC cells (Artalejo et al., 1990; 1991a), but such treatments were ineffective in augmenting $\mathrm{Ca}$ currents in adult AC cells [data not shown (also see Engisch and Nowycky, 1996)].

\section{Distinct role of facilitation Ca channels in catecholamine secretion from calf AC cells}

To determine whether facilitation $\mathrm{Ca}$ channels recruited by APs contribute to catecholamine secretion in calf AC cells, we stimulated the cells at $7 \mathrm{~Hz}$ with APs while recording catecholamine release amperometrically using an extracellular carbon-fiber electrode (Fig. 3). We found that in two successive $70 \mathrm{sec}$ stimulation periods, secretion in the second round, as quantitated by cumulative amperometric spike amplitude, was very similar to that in 


\section{A CALF}

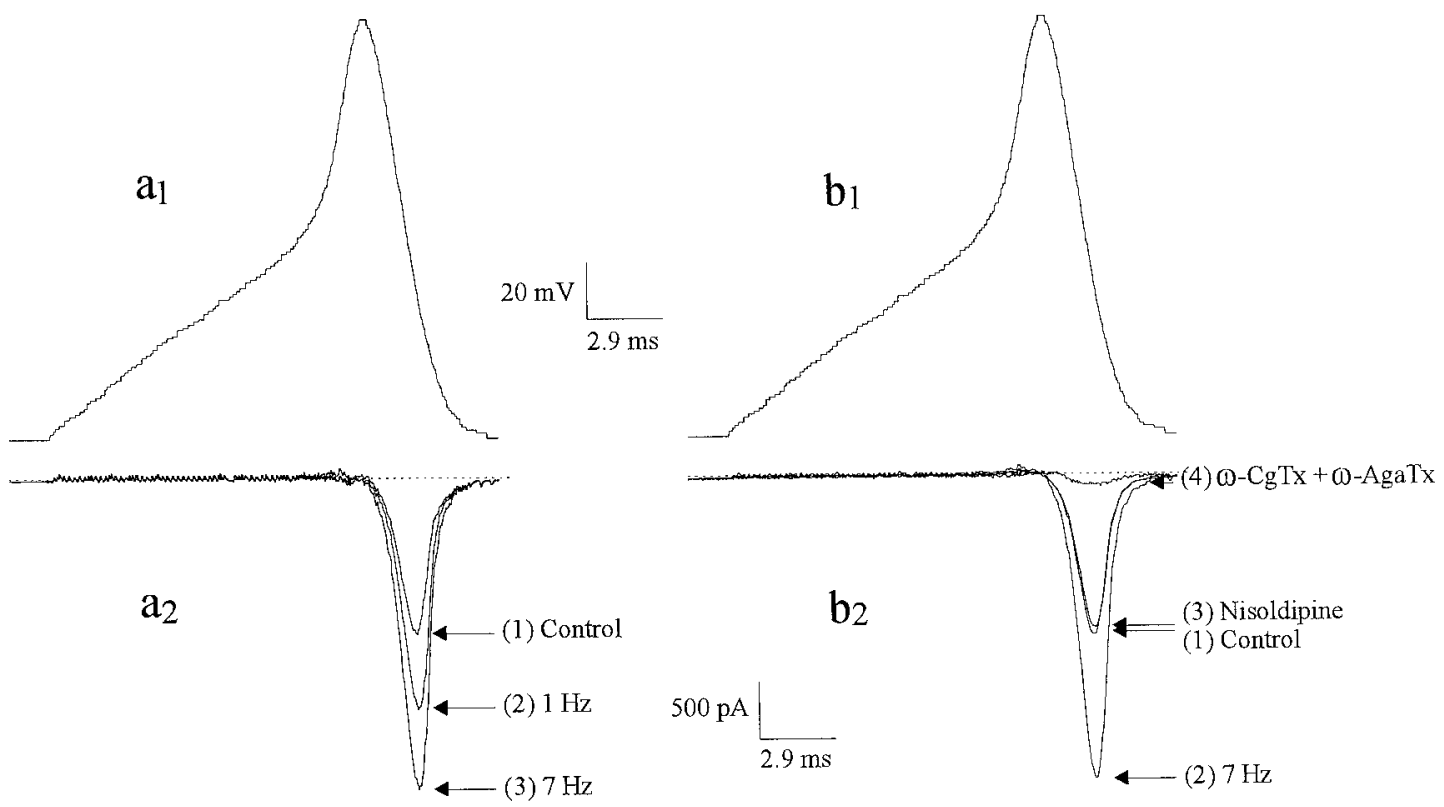

B

ADULT

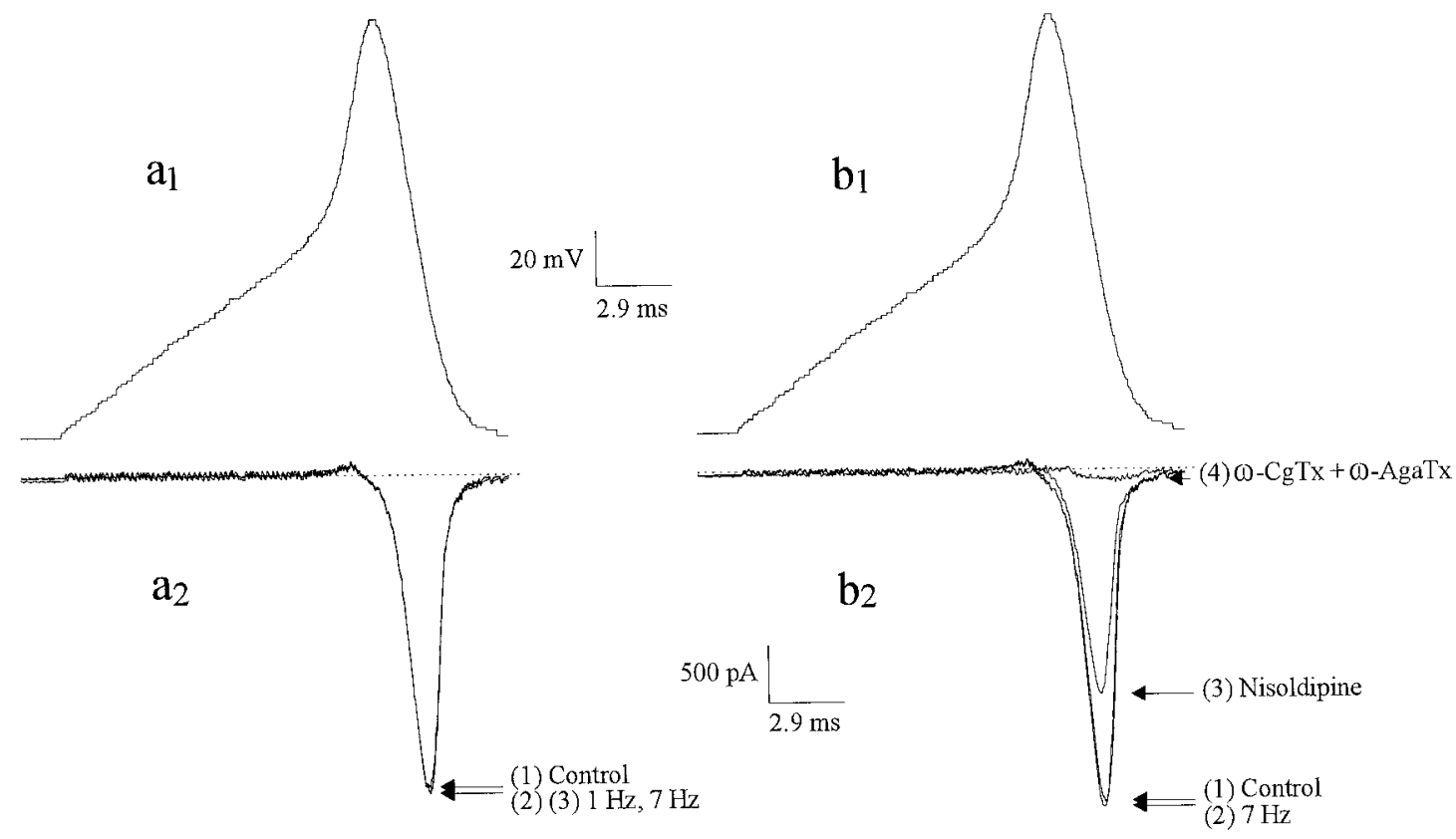

Figure 1. Action potential waveforms (APWs) recruit facilitation L-current in AC cells from calf but not adult cattle. To mimic Ca channel activation by depolarizing secretagogues such as ACh, we recorded APs in current clamp and played them back as voltage-clamp commands (APWs) in $(A)$ calf and $(B)$ adult bovine AC cells. At left, Ca currents elicited by single APWs $\left(a_{1}\right)$ before and after a train of $20 \mathrm{APWs}$ delivered at 1 and $7 \mathrm{~Hz}$ in the same cell are shown; 4 min was allowed for recovery between trains. The superimposed current traces are (1) control Ca current and (2 and 3 ) Ca current at the end of the 1 or $7 \mathrm{~Hz}$ train. Note that in $A$, APWs delivered at $1 \mathrm{~Hz}$ increased the $\mathrm{Ca}$ current by $48 \%$, whereas at $7 \mathrm{~Hz}$ the Ca current was increased by $98 \%$; in $B$ no change was observed at either frequency, indicating the absence of facilitation. At right, Ca currents $\left(b_{2}\right)$ elicited by a single APW $\left(b_{1}\right)$ before and after three consecutive trains of $20 \mathrm{APWs}$ at $7 \mathrm{~Hz}$ in the absence $(1,2)$ or presence of nisoldipine $(1 \mu \mathrm{M})$, alone (3) or plus $\omega$-CgTx (500 $\mathrm{nM})+\omega$-AgaTx (10 nM) (4); a 4 min interval was allowed for recovery and application of antagonists. Nisoldipine selectively suppressed the increased Ca current brought about by the $7 \mathrm{~Hz}$ stimulation in calf $(A)$ and decreased a component of Ca current (presumed "standard" L-type) in adult ( $B$ ); the remaining current was almost completely suppressed by the addition of $\omega$-CgTx $+\omega$-AgaTx. 


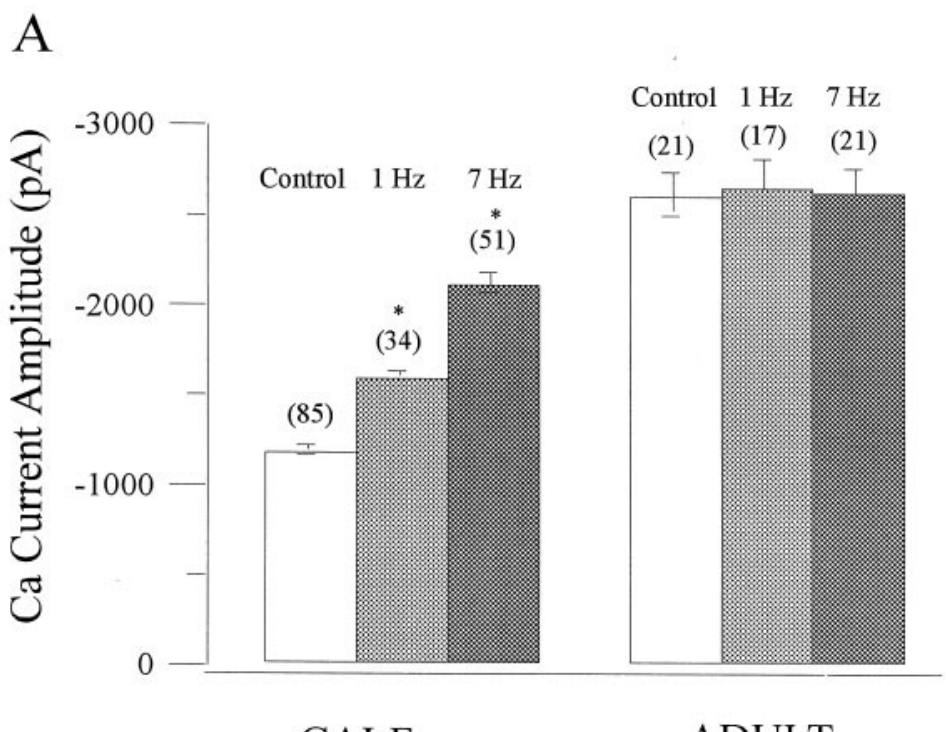

CALF

B

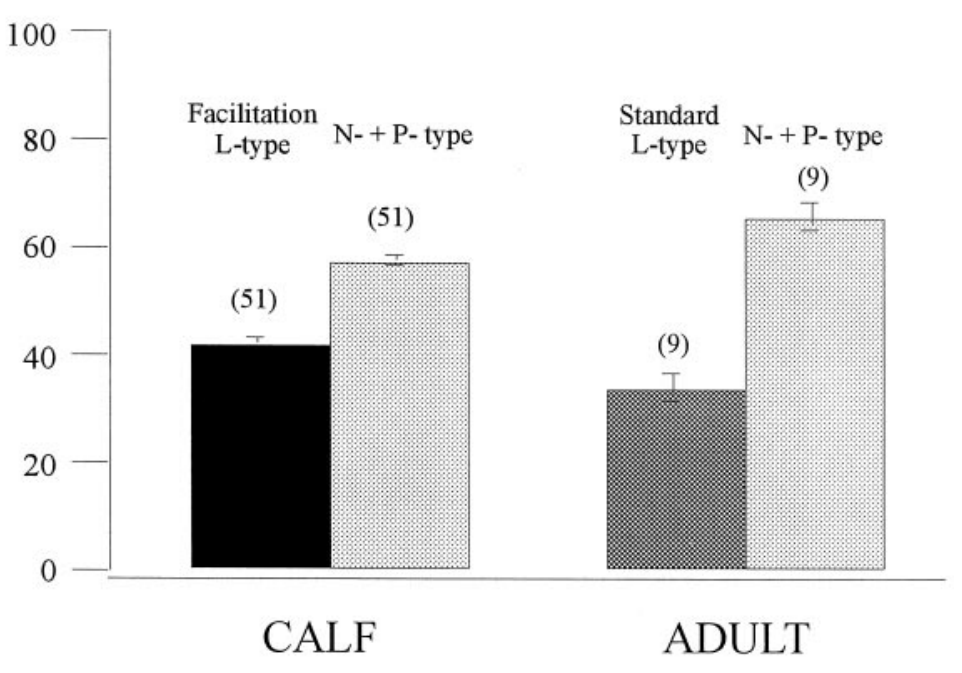

Figure 2. Statistical analysis of Ca currents in $\mathrm{AC}$ cells from calf versus adult cattle: AP stimulation frequency and antagonist effects. $A$, Effect of AP stimulation frequency on the peak Ca current amplitude at the end of a train of 20 APWs at 1 or $7 \mathrm{~Hz}$. Values are mean $\pm \mathrm{SEM} ; n$ is indicated in parentheses above each bar. *, Significantly different from the corresponding control at $p<0.0001$. B, Pharmacological dissection of the Ca current components, evoked by APWs at $7 \mathrm{~Hz}$, shows that facilitation L-type constitutes $42.32 \pm$ $0.93 \%$ of the total $\mathrm{Ca}$ current in calf AC cells, whereas standard L-type contributes $34.1 \pm 2.53 \%$ to the total current in adult AC cells. the first round, indicating that secretion shows no sign of exhaustion under these conditions (Fig. $3 A, a_{3}$ ). When the second stimulation round was conducted in the presence of nisoldipine, the rate and extent of catecholamine secretion were significantly $(>40 \%)$ depressed and showed a lag (Fig. $3 A, a_{2}, a_{3}$; Table 1). These results suggest that facilitation $\mathrm{Ca}$ channels contribute substantially to catecholamine release under these conditions. Despite the presence of sizeable Ca currents in adult AC cells, the magnitude of secretion was only $\sim 50 \%$ of that exhibited by calf cells for comparable amounts of stimulation (Figs. 2, 3B, $b_{1}$; Table 1), but again remained undiminished in successive rounds of stimulation (Fig. $2 B, b_{3}$ ). Nisoldipine did not cause a significant lag in the onset of secretion but significantly depressed catecholamine release in adult AC cells, indicating that standard (nonfacilitated) L-type $\mathrm{Ca}$ channels are involved in secretion in these cells (Fig. $3 B, b_{2}, b_{3}$; Table 1 ).

A key role for facilitation $\mathrm{Ca}$ channels in the onset of the secretory response also became apparent in these experiments. On recruitment of these channels in calf $\mathrm{AC}$ cells, secretion started within $1 \mathrm{sec}$ of the beginning of the stimulus train. However, in nisoldipine-treated calf AC cells, secretion only began after a lag of $9 \sec$ (Fig. 3, $a_{3}, a_{4}$ ). Similar results were previously obtained when changes in membrane capacitance were used as an assay of catecholamine secretion in calf AC cells (Artalejo et al., 1994, their Fig. 2). A lag of 6-9 sec was also present in adult AC cells and was not altered significantly by the presence of nisoldipine (Fig. 3, $b_{3}, b_{4}$ ). Thus the prompt onset of secretion in calf AC cells is dependent on the recruitment of facilitation $\mathrm{Ca}$ channels.

\section{Strong stimulus-secretion coupling is predominant in calf $A C$ cells but not in adult $A C$ cells}

We used amperometric latency histograms (Chow et al., 1992, 1994, 1996) to quantitate the delay between the peak of the preceding AP and the onset of extracellular amperometric spikes in calf AC cells (Fig. 4A). Spikes that occurred $<25$ msec after the action potential were operationally classified as "strongly coupled," whereas those taking place $>25 \mathrm{msec}$ after the action potential were termed "weakly coupled." To illustrate the cou- 


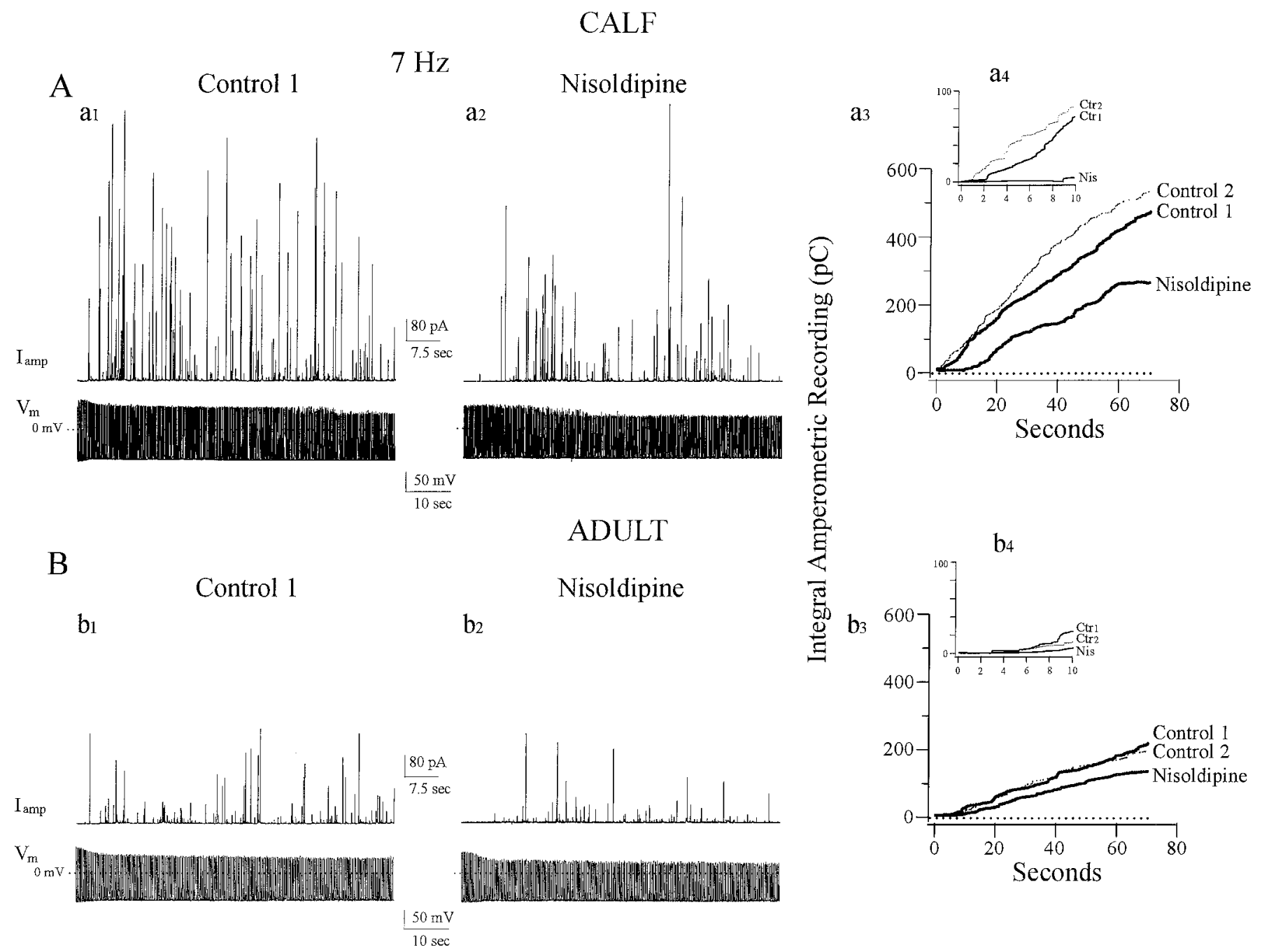

Figure 3. Distinct role of facilitation Ca channels in catecholamine secretion from calf AC cells. $A$, Calf AC cells were stimulated with trains of APs in current-clamp mode together with amperometric detection of catecholamine secretion. Amperometric spikes $\left(I_{\text {amp }}\right)$ were generated in response to trains of single APs $\left(\mathrm{V}_{\mathrm{m}}\right)$ evoked by short depolarizing current pulses at a frequency of $7 \mathrm{~Hz}\left(a_{1}\right)$. Sequential trains of $490 \mathrm{APs}$ at $7 \mathrm{~Hz}$ resulted in successive secretory episodes monitored as barrages of amperometric spikes; a 6 min rest period separated each train. As quantitated by the cumulative integral of the amperometric current $\left(a_{3}\right)$, the second round (Control 2) was always slightly increased relative to the first (Control 1), indicating that secretion shows no sign of exhaustion under these conditions (average increase in the second round was $12.8 \pm 0.9 \% ; n=44$ ). To determine whether facilitation $\mathrm{Ca}$ channels contribute to catecholamine secretion in calf AC cells, nisoldipine was added between trains. Secretion was substantially reduced under these conditions $\left(a_{2}, a_{3}, 44 \%\right.$ inhibition compared with secretion in the first round). Inset $\left(a_{4}\right)$ shows expanded time base for the first 10 sec of AP-stimulated secretion. When facilitation Ca channels are recruited (Ctr1 and Ctr2), secretion starts within the first second of stimulation, whereas after nisoldipine (Nis) secretion only starts after a lag of $\sim 9$ sec. B. Adult AC cells treated under conditions identical to those shown in $A$. Instead of enhancement, a slight depression in cumulative secretion was seen in the second round of stimulation $\left(b_{3}\right.$, Control 1 , Control 2$)$. When nisoldipine was applied before the second round of stimulation, the signal was further depressed $\left(b_{2}, b_{3}, 37 \%\right.$ inhibition) indicating that conventional L-type Ca channels contribute to secretion in these cells. Inset $\left(b_{4}\right)$ shows that all three types of $\mathrm{Ca}$ channels found in adult AC cells promote secretion, but with an average lag of $6 \mathrm{sec}$; after nisoldipine the lag is $\sim 9 \mathrm{sec}$.

pling between APs and the amperometric spikes in calf AC cells stimulated at $1 \mathrm{~Hz}$, a representative record is shown in Figure $4 B$. Low-frequency stimulation gave rise to amperometric spikes that were all $(0.25 \mathrm{~Hz})$ or almost all $(1 \mathrm{~Hz})$ strongly coupled to the AP (Fig. $4 C, c_{1}, c_{2}$ ). The average delay between AP and amperometric spike was $\sim 3 \mathrm{msec}$ at these frequencies. When stimulation was increased to $7 \mathrm{~Hz}$, a greater variation in latencies was observed; in addition to the strongly coupled peak at $3 \mathrm{msec}$, a plateau component with delays of $25-143 \mathrm{msec}$ was also found in these histograms (Fig. $4 C, c_{3}$ ). The decay time constant $(\tau)$ of the strongly coupled peak in these histograms was 3-4 msec at all frequencies (Table 1). This value is used to compute the approx- imate distance between facilitation $\mathrm{Ca}$ channels and release sites (see below). To further test the idea that the strongly coupled component of secretion is caused by the activity of $\mathrm{Ca}$ channels that are preferentially associated with release sites, we performed experiments in which the amount of $\mathrm{Ca}$ entering the cell during stimulation was varied by changing external [Ca]. At high rates of stimulation $(7 \mathrm{~Hz})$, reduction of external [Ca] from 2 to $0.25 \mathrm{~mm}$ selectively abolished the weakly coupled signals but had no effect on the strongly coupled peak in latency histograms (data not shown). One explanation for these results is that the lower amount of $\mathrm{Ca}$ entering under these conditions fails to elicit secretion at distant sites that contribute to the weakly coupled 


\begin{tabular}{|c|c|c|c|c|c|}
\hline Condition & $\tau(\mathrm{msec})$ & $\%$ Events $\leq 25 \mathrm{msec}$ & $\%$ Events $\geq 25 \mathrm{msec}$ & Integral $Q_{\text {amp }}(\mathrm{pC})$ & Rate (pC/sec) \\
\hline Calf, $0.25 \mathrm{~Hz}$, control $(n=19)$ & $3.18 \pm 0.08$ & $93.3 \pm 1.05^{a}$ & $6.7 \pm 1.05$ & & \\
\hline Calf, $1 \mathrm{~Hz}$, control $(n=144)$ & $2.92 \pm 0.08$ & $78.72 \pm 0.68^{a}$ & $21.28 \pm 0.68$ & & \\
\hline Calf, $1 \mathrm{~Hz}$, nisoldipine $(n=13)$ & & $15.13 \pm 2.23$ & $84.83 \pm 2.21$ & & \\
\hline Calf, $7 \mathrm{~Hz}$, control $(n=109)$ & $3.16 \pm 0.08$ & $40 \pm 0.1^{a}$ & $60 \pm 0.1$ & $374.7 \pm 9.97^{b, c, d}$ & $5.39 \pm 0.16^{b, c, d}$ \\
\hline Calf, $7 \mathrm{~Hz}$, nisoldipine $(n=20)$ & & $14.75 \pm 1.13$ & $85.25 \pm 1.13$ & $216 \pm 13^{b}$ & $3.35 \pm 0.25^{b}$ \\
\hline Calf, $7 \mathrm{~Hz}, \omega$-CgTx $+\omega$-AgaTx & & & & & \\
\hline$(n=12)$ & $3.38 \pm 0.27$ & $70 \pm 0.51^{a}$ & $30 \pm 0.51$ & $174 \pm 3.4^{d}$ & $2.53 \pm 0.1^{d}$ \\
\hline Adult, $1 \mathrm{~Hz}$, control $(n=20)$ & & $10.2 \pm 1.4$ & $89.8 \pm 1.4$ & & \\
\hline Adult, $1 \mathrm{~Hz}$, nisoldipine $(n=9)$ & & $13.56 \pm 0.83$ & $86.44 \pm 0.83$ & & \\
\hline Adult, $7 \mathrm{~Hz}$, control $(n=22)$ & & $14.1 \pm 0.75$ & $85.9 \pm 0.75$ & $203.4 \pm 12.3^{c}$ & $2.99 \pm 0.19^{c}$ \\
\hline Adult, $7 \mathrm{~Hz}$, nisoldipine $(n=13)$ & & $12.2 \pm 0.9$ & $87.8 \pm 0.9$ & $131.3 \pm 8.3^{b, c, d}$ & $1.91 \pm 0.12^{b, c, d}$ \\
\hline $\begin{array}{l}\text { Adult, } 7 \mathrm{~Hz}, \omega \text {-CgTx }+\omega \text {-AgaTx } \\
\quad(n=12)\end{array}$ & & $14 \pm 0.4$ & $86 \pm 0.4$ & & \\
\hline
\end{tabular}

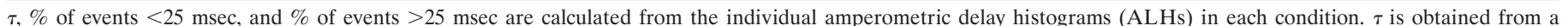

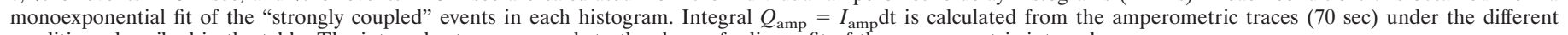
conditions described in the table. The integral rate corresponds to the slope of a linear fit of the amperometric integral.

$a, b, c, d$ These values are significantly different from each other at $p<0.0001$. Measurements are given as means \pm SEM.

signal because of cytoplasmic Ca buffering (Klingauf and Neher, 1997).

Latency histograms in AC cells from adult cattle revealed no strongly coupled peak component at any stimulation frequency (Fig. 4D). Instead, a plateau of delay values stretching from 0 to 143 msec was observed. Although some events with latencies $<25$ msec were found (Fig. $4 D, d_{2}$ ), they comprised only $\sim 14 \%$ of the total signal (Table 1) and thus may correspond to a "randomly colocalized" component of secretion in this cell type, as suggested in previous studies (Chow et al., 1994; Zhou and Misler, 1995; Klingauf and Neher, 1997). The behavior of the two cell types at $0.25 \mathrm{~Hz}$ was particularly striking: in calf cells, substantial rapid secretion occurred but no secretion could be evoked from adult cells (Fig. 4, compare $c_{1}, d_{1}$ ).

\section{Strong stimulus-secretion coupling is caused by activation of facilitation L-type $\mathbf{C a}$ channels}

To examine the role of different $\mathrm{Ca}$ channels in the patterns of secretion observed above, we performed amperometric latency histogram analyses in the presence of toxins that differentially target either L-type (nisoldipine) or non-L-type ( $\omega$-conotoxin + $\omega$-agatoxin) $\mathrm{Ca}$ channels (Fig. 5, Table 1). In calf AC cells, nisoldipine eliminated the strongly coupled peak of secretion at all frequencies but only attenuated the appearance of the weakly coupled plateau at $7 \mathrm{~Hz}$. By contrast, $\omega$-conotoxin plus $\omega$-agatoxin did not affect the short-latency peak at any frequency, but strongly depressed $(77 \%)$ the weakly coupled plateau seen at 7 $\mathrm{Hz}$. These results clearly suggest that facilitation L-type Ca channels are responsible for strong stimulus-secretion coupling in calf AC cells, whereas N- and P-type channels contribute substantially to delayed secretion. In AC cells from adults, nisoldipine or the toxin combination simply reduced secretion at all latencies to virtually the same extent, indicating that all three channel types play approximately equivalent roles in secretion from these cells. These results are summarized in Table 1.

\section{Facilitation channels are within $13 \mathrm{~nm}$ of release sites in calf chromaffin cells}

There are several possible explanations for the close relationship between facilitation $\mathrm{Ca}$ channels and catecholamine secretion (see Discussion). One possibility, favored by us, is that these data reflect colocalization of these channels and secretory sites. Klingauf and Neher (1997) elaborated a model based on amperometric histograms similar to those used here that allowed them to calculate the average distance between $\mathrm{Ca}$ channels and secretory sites in adult bovine AC cells. The main assumption made in this model is that release-ready granules are randomly distributed within a regularly spaced grid of $\mathrm{Ca}$ channels with a constant interchannel distance. Klingauf and Neher (1997) determined that most vesicles were located at substantial distances from $\mathrm{Ca}$ channels but that a very minor fraction $(\sim 8 \%)$ were randomly colocalized with Ca channels. We have used this model and their data to derive an empirical function describing the algebraic relationship between the average distance $(\delta)$ from Ca channels to release sites and the decay time constant $(\tau)$ of the amperometric latency histogram (Fig. 6). In addition to points derived from the data of Klingauf and Neher (1997), we use a third point estimated from studies on synaptic release (Adler et al., 1991; Lando and Zucker, 1994; Roberts, 1994). The distance between $\mathrm{Ca}$ channels and release sites at synapses has been estimated to be $\sim 10 \mathrm{~nm}$, and fast release is accomplished within 1-2 msec (Sabatini and Regehr, 1996). After graphing the appropriate function, we then determined by interpolation that a $\tau$ value of 3.1 msec (derived from Table 1, line 1) yields a $\delta$ value of $13 \mathrm{~nm}$ for the average distance between facilitation $\mathrm{Ca}$ channels and release sites in calf AC cells. A variable in the Klingauf-Neher model is the magnitude of the $\mathrm{Ca}$ current. Larger $\mathrm{Ca}$ currents would lead to a reduction in the estimated average distance between $\mathrm{Ca}$ channels and release sites. In adult AC cells, Klingauf and Neher (1997) used a value of $500 \mathrm{pA}$, which is about half the average Ca current through facilitation channels found in the present study $(\sim 1000 \mathrm{pA} ; 927.1 \pm 55.73 ; n=51)$ (Fig. 2$)$. With their assumptions that (1) all Ca channels are evenly/randomly distributed and (2) all $\mathrm{Ca}$ channels have a similar conductance, for a given whole-cell $\mathrm{Ca}$ current $\left(I_{\mathrm{Ca}}\right)$ the following relationship can be derived: $\delta=300 \times\left(500 / I_{\mathrm{Ca}}\right)^{1 / 2}$, where $\delta$ is in nanometers and $I_{\mathrm{Ca}}$ is in picoamperes. According to this relationship, increasing the Ca current from 500 to $1000 \mathrm{pA}$ in the Klingauf-Neher model would reduce $\delta$ values by $\sim 30 \%$ (e.g., from 300 to $212 \mathrm{~nm}$ for the bulk of the noncolocalized vesicles and from 30 to $21.2 \mathrm{~nm}$ for the randomly colocalized population). The $\delta$ value for the noncolo- 
A

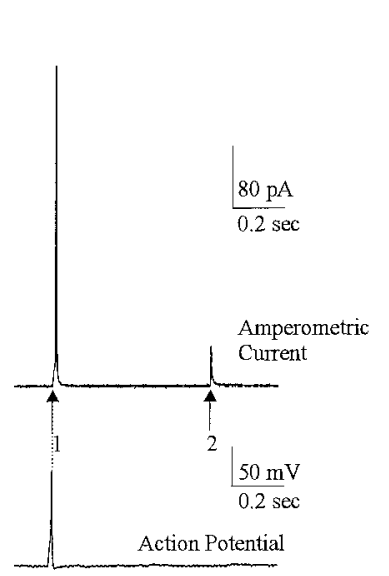

B

CALF

$1 \mathrm{~Hz}$

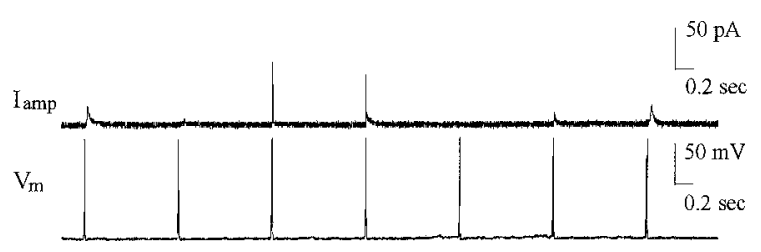

C
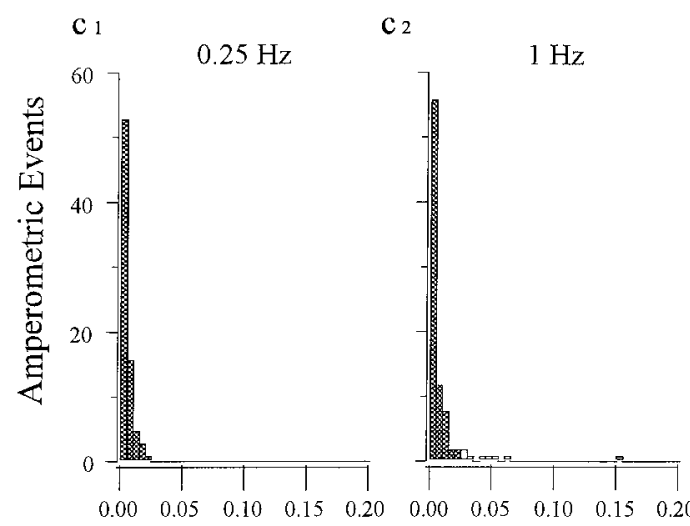

$\mathrm{b}_{3}$

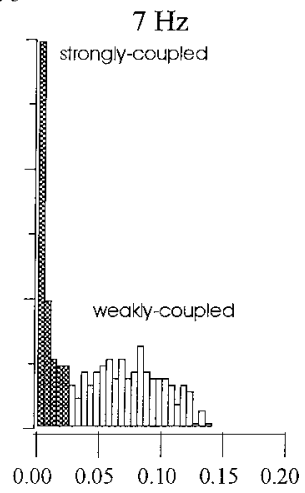

Delay (sec)
D

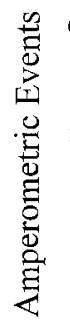

$\mathrm{d}_{2}$ $0.25 \mathrm{~Hz}$

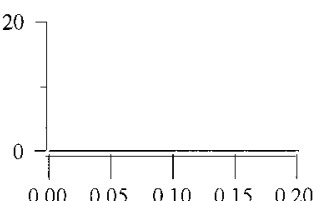

ADULT

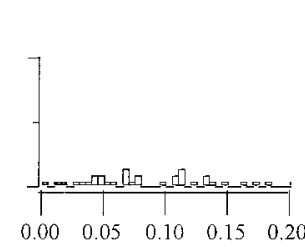

$\mathrm{d}_{3}$

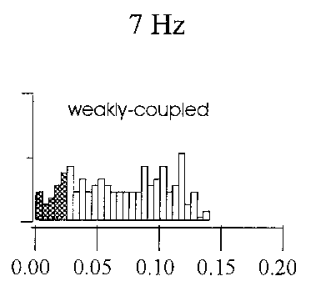

Delay (sec)

Figure 4. Strong stimulus-secretion coupling is predominant in calf AC cells but not in adult AC cells. To quantitate the delay between the onset of stimulation and detection of amperometric spikes from calf and adult AC cells, we analyzed latency histograms. $A$, In such histograms, "coupling" is defined as the degree of coincidence between APs and the subsequent amperometric spike(s). The time from the peak of the AP (vertical dashed line) to the beginning of a current spike (indicated here by arrows 1 and 2) is termed latency, and these are collected and displayed as latency histograms (Chow et al., 1992). B, Representative amperometric spikes $\left(I_{\mathrm{amp}}\right)$ generated from a calf AC cell in response to trains of single APs $\left(\mathrm{V}_{\mathrm{m}}\right)$ evoked at $1 \mathrm{~Hz}$ illustrate the coupling between APs (bottom trace) and amperometric spikes (top trace). $C$, Latency histograms of multiple events collected from calf AC cells stimulated by single APs applied at $0.25 \mathrm{~Hz}\left(c_{1}\right), 1 \mathrm{~Hz}\left(c_{2}\right)$, or $7 \mathrm{~Hz}\left(c_{3}\right)$, respectively. Filled bars represent "strongly coupled" signals with latency $<25 \mathrm{msec}$, whereas open bars represent "weakly coupled" signals (latency $25-143 \mathrm{msec}$ ). At $0.25 \mathrm{~Hz}$, nearly all amperometric spikes (97\%) are strongly coupled; at $1 \mathrm{~Hz}, 83 \%$ are strongly coupled, whereas the remaining events form a dispersed tail. At $7 \mathrm{~Hz}, 40 \%$ of events are strongly coupled, whereas the other $60 \%$ are weakly coupled. $D$, Latency histograms from adult AC cells stimulated under conditions identical to those shown in $C$. No events were apparent at $0.25 \mathrm{~Hz}\left(d_{1}\right)$, and only a plateau component of latencies from 0 to $143 \mathrm{msec}$ was observed at 1 and $7 \mathrm{~Hz}\left(d_{2}, d_{3}\right)$. Only 4 and $14 \%$ of the total events had a latency $<25 \mathrm{msec}$ at 1 and $7 \mathrm{~Hz}$, respectively. Latency histograms in $C$ and $D$ were determined from different cells stimulated by similar number of APs at each frequency, of which only $200 \mathrm{msec}$ is shown $450 \mathrm{APs}\left(c_{1}, d_{1}, 0.25 \mathrm{~Hz}\right), 490 \mathrm{APs}\left(c_{2}, d_{2}, 1 \mathrm{~Hz}\right)$, and $490 \mathrm{APs}\left(c_{3}, d_{3}, 7 \mathrm{~Hz}\right)$. Only amperometric events having $50-90 \%$ rise time faster than $3 \mathrm{msec}$ were selected for these histograms.

calized population is still much larger than the $13 \mathrm{~nm}$ distance between facilitation $\mathrm{Ca}$ channels and release sites calculated for calf AC cells (Fig. 6). Thus the latter value cannot be explained by the large facilitation Ca current of $\sim 1000 \mathrm{pA}$ found in the present study and must be caused by another factor, such as the colocalization suggested here.

\section{DISCUSSION}

Previous analyses of stimulus-secretion coupling in neuroendocrine cells led to the supposition that the kinetics of secretion from dense-core vesicles is generally much slower than that from small synaptic vesicles in neurons. The results presented here show that dense-core vesicles can exhibit rates of secretion quite comparable to those found in neurons and that this depends on the proximity of these vesicles to a specific subtype of Ca channel. We hypothesized previously that facilitation L-type Ca channels are colocalized with sites of exocytosis in calf AC cells, based on capacitance measurements in the presence of specific antagonists of the different Ca channels present in these cells (Artalejo et al., 1994). In the present work we demonstrate that APWs are able to recruit these same facilitation $\mathrm{Ca}$ channels in a manner indistinguishable from that seen previously with single, large, squarewave depolarizing prepulses or pulse trains in the physiological range (Artalejo et al., 1991a,b). Consequently, facilitation $\mathrm{Ca}$ channels do become active under physiologically relevant conditions, because acetylcholine leads to trains of action potentials in these cells (Douglas et al., 1967). We then used amperometry to 
A

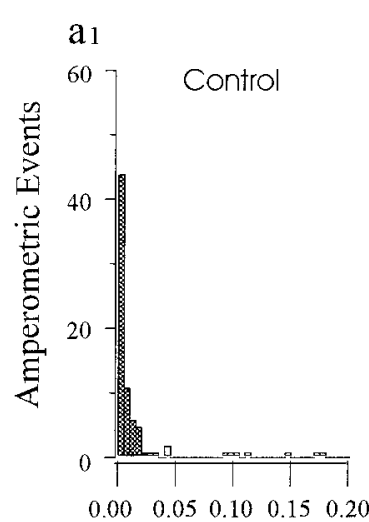

$1 \mathrm{~Hz}$

a 2

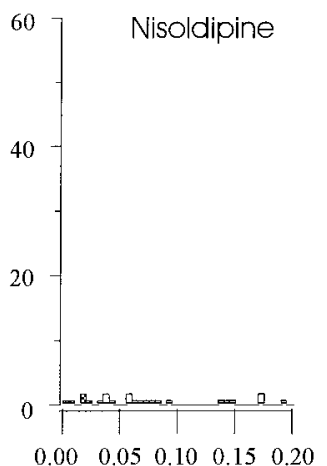

CALF

a 3

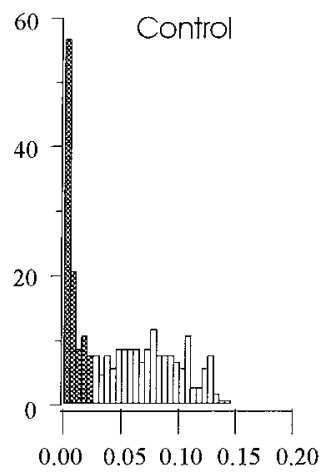

Delay (sec)
$7 \mathrm{~Hz}$
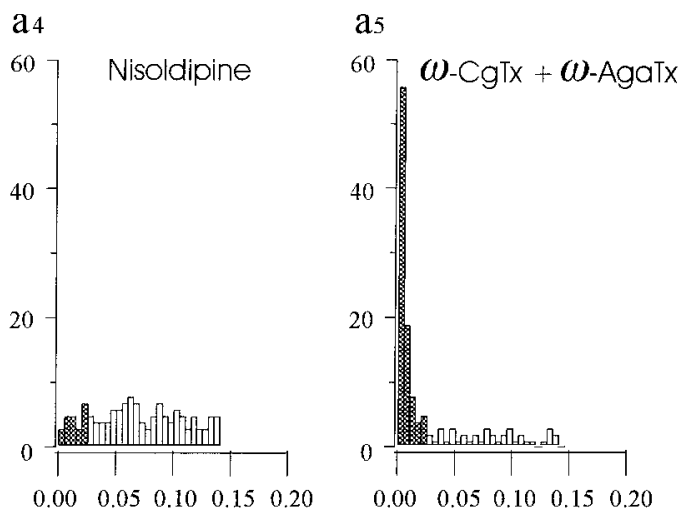

B

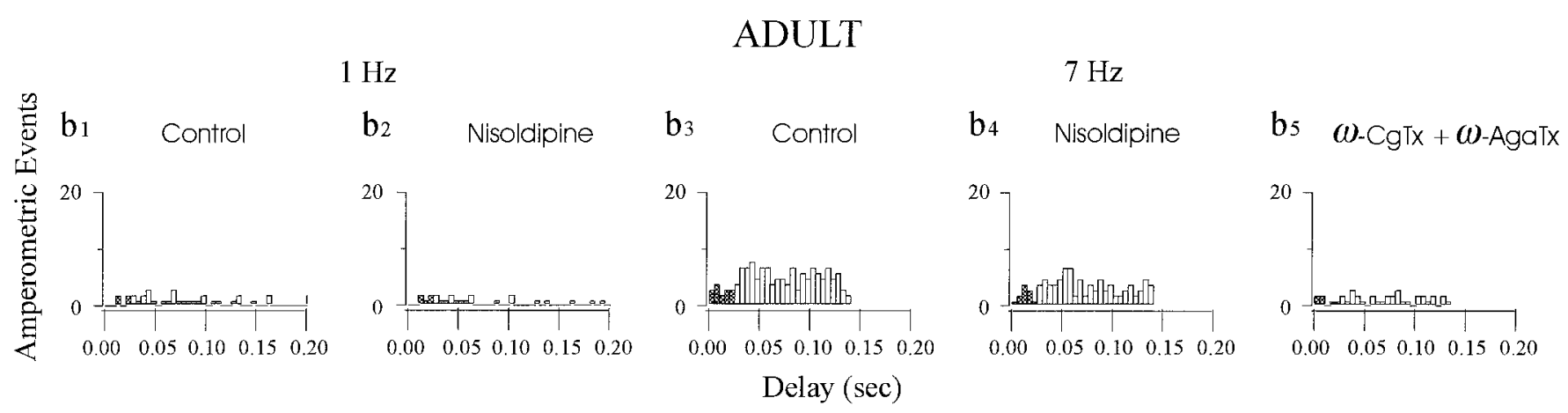

Figure 5. Strong stimulus-secretion coupling is attributable to activation of facilitation L-type Ca channels. To determine the proximity of different types of $\mathrm{Ca}$ channels to release sites and their contribution to secretion at different frequencies, we analyzed latency histograms from amperometric experiments in the presence of antagonists that selectively block L-type (nisoldipine) or N-type [ $\omega$-Conotoxin-GVIA ( $\omega$-CgTx)] and P-type [ $\omega$-Agatoxin-IVA $(\omega$-AgaTx)] Ca channels. $A$, Nisoldipine eliminates the strongly coupled peak of secretion at all frequencies in calf AC cells. Latency histograms were derived from the amperometric spikes that resulted from two successive stimulation periods of $1 \mathrm{~Hz}\left(a_{1}, a_{2}, 490 \mathrm{APs}\right.$ each) or $7 \mathrm{~Hz}\left(a_{3}\right.$, $a_{4}, 490 \mathrm{APs}$ each) in the absence (Control, $a_{1}, a_{3}$ ) or presence of nisoldipine (Nisoldipine, $\left.a_{2}, a_{4}\right)$. At $7 \mathrm{~Hz}$, nisoldipine suppressed $85 \%$ of events with latencies $<25 \mathrm{msec}$ and $30 \%$ of those with latencies $>25 \mathrm{msec}$ after the AP (49\% of total events). In parallel experiments $\left(a_{5}\right.$, $>490$ APs), the combination of $\omega$-CgTx and $\omega$-AgaTx had little effect on the short-latency responses (reduced $14 \%$ of events $<25$ msec) but eliminated $77 \%$ of events from the weakly coupled plateau (53\% of total events). $B$, Latency histograms derived from adult AC cells using an experimental protocol similar to that shown in $A: 1 \mathrm{~Hz}\left(b_{1}, b_{2}, 490 \mathrm{APs}\right), 7 \mathrm{~Hz}\left(b_{3}, b_{4}, 490 \mathrm{APs}\right)$ stimulation, each set from the same cell, in the absence (Control, $a_{1}$ and $\left.a_{3}\right)$ or presence of nisoldipine (Nisoldipine, $b_{2}, b_{4}$ ), or $7 \mathrm{~Hz}\left(b_{5}\right)$ in the presence of $\omega$-CgTx $+\omega$-AgaTx. At $7 \mathrm{~Hz}$, in comparison with the control, 30 and $69 \%$ of total events were suppressed by nisoldipine or the combination of toxins, respectively.

define the delay or latency between the peak of the evoked AP and the onset of catecholamine secretion from dense-core vesicles. Both strong and weak coupling between AP stimulation and secretion was found in calf AC cells, based on analysis of amperometric spike latency histograms. Strong coupling, defined as a delay of $<25$ msec between the AP and the amperometric spike, manifested as a peak at all stimulation frequencies, whereas weak coupling (delay $>25 \mathrm{msec}$ ) was substantial only at higher frequencies and comprised a plateau of values stretching to $\sim 143 \mathrm{msec}$. Nisoldipine was able to selectively abolish the strongly coupled signal at all stimulation frequencies, indicating that this peak in the latency histogram is mediated by facilitation L-type Ca channels. Because the latency is a measure of the coupling between ports of $\mathrm{Ca}$ entry and release sites, these results support our previous contention that facilitation L-type $\mathrm{Ca}$ channels are located closer to release sites than other types of $\mathrm{Ca}$ channel found in calf AC cells (Artalejo et al., 1994). Consistent with this scenario, weakly coupled, but not strongly coupled, stimulussecretion responses were dependent on $\mathrm{Ca}$ influx via $\mathrm{N}$ - and P-type $\mathrm{Ca}$ channels because these long-latency signals were reduced by the combination of $\omega$-conotoxin and $\omega$-agatoxin. There are other possible explanations of the efficiency with which facilitation $\mathrm{Ca}$ channels elicit secretion in calf AC cells. For example, such channels could be clustered, thus providing a locus for large local increases in submembrane $\mathrm{Ca}$ that could trigger with greater efficiency the secretion of DCVs that happened to be close by. Although this is evidently a possibility, our previous singlechannel data suggested that clusters of facilitation Ca channels do not exist in calf AC cells (Artalejo et al., 1990, 1991b). Moreover, large local changes in $\mathrm{Ca}$ attributable to influx at a hypothetical $\mathrm{Ca}$ channel cluster would be expected to spread laterally and cause release of vesicles at some distance from the cluster. Such 


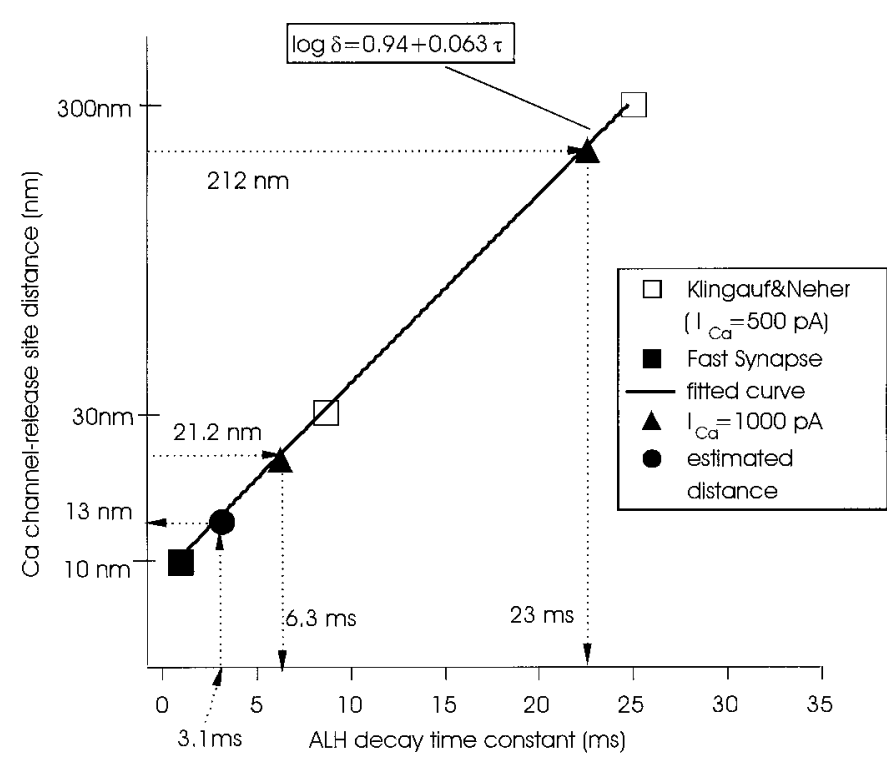

Figure 6. Estimated distance between facilitation $\mathrm{Ca}$ channels and the adjacent release site. To estimate $\delta$ from the decay time constant $(\tau)$ of an amperometric latency histogram $(A L H)$, an empirical function was obtained by a standard optimum fit procedure of data describing the relationship between $\mathrm{Ca}$ channels and secretory sites in adult AC cells (Klingauf and Neher, 1997). In that model, two points $(\tau=8.7 \mathrm{msec}, \delta=$ $30 \mathrm{~nm} ; \tau=25 \mathrm{msec}, \delta=300 \mathrm{~nm}$ ) were calculated from a specific set of conditions prevalent in those cells $(\square)$. To derive the empirical function, we added a third point ( $\delta=10 \mathrm{~nm}, \tau=1 \mathrm{msec}$; $)$ derived from work on synaptic terminals (Adler et al., 1991; Lando and Zucker, 1994; Roberts, 1994; Sabatini and Regehr, 1996). An optimum fit with the three points ( $\tau$ $=1, \delta=10 ; \tau=8.7 \mathrm{msec}, \delta=30 \mathrm{~nm} ; \tau=25 \mathrm{msec}, \delta=300 \mathrm{~nm}$ ) results in an empirical formula $\log \delta=0.94+0.063 \tau$. The resultant equation was plotted, and the known $\tau$ value of $3.1 \mathrm{msec}$ derived from the latency histogram at $0.25 \mathrm{~Hz}$ (Table 1) was used to determine the corresponding $\delta$ value of $13 \mathrm{~nm}$ by interpolation (0). The triangles show modified data points of Klingauf and Neher (1997), corrected for $1000 \mathrm{pA} \mathrm{Ca}$ current (A) (see Results for details).

events should appear as a "tail" in amperometry histograms, but at low stimulation frequencies no tail was observed (Fig. 3B,C). Yet another possibility is that intracellular $\mathrm{Ca}$ buffering may differ (i.e., be weaker) in the region around facilitation $\mathrm{Ca}$ channels compared with other parts of the sub-plasma membrane domain. Once again, in this model one would anticipate that the spread of $\mathrm{Ca}$ from facilitation channels would be significant and give rise to a tail in latency histograms. Moreover, it has been suggested that the sustained increase in $[\mathrm{Ca}]_{\mathrm{i}}$ and the mobile buffers should be similar for all three types of channels (Nowycky and Pinter, 1993; Zhou and Neher, 1993). Although we favor the colocalization model, further studies will be necessary to demonstrate a molecular link between facilitation channels and the secretory apparatus.

In their extensive analysis of secretion from adult bovine $\mathrm{AC}$ cells, Neher's group (Chow et al., 1992, 1994, 1996) concluded that there was little evidence for coupling of $\mathrm{Ca}$ channels with release sites, and similar conclusions were reached in adult rat $\mathrm{AC}$ cells (Zhou and Misler, 1995). With the assumption that latencies reflect distances, recent modeling data suggested that the average distance between most Ca channels and release sites is 200-300 $\mathrm{nm}$ in these cells (Klingauf and Neher, 1997), assuming these elements to be symmetrically distributed. A small $(<10 \%)$ fraction of $\mathrm{Ca}$ channels was proposed to be located in a stochastic manner closer to release sites $(\sim 30 \mathrm{~nm})$, to explain an asymmetry in latency histograms biased toward shorter events [also see Zhou and Misler (1995)]. Our results with adult AC cells are largely in agreement with those of Chow et al. (1992, 1994, 1996). We found a wide range of latencies with only $\sim 10 \%$ of events showing a delay of $<25 \mathrm{msec}$; no distinct early peak appeared in amperometric latency histograms, because of the absence of facilitation L-type Ca channels in these cells. Instead, a standard L-type Ca current that was not increased by large prepulses, repetitive depolarization in the physiological range, or cAMP but was sensitive to nisoldipine is present. Pharmacological suppression of either this current or other types of Ca channels in these cells did not affect a particular part of the latency histogram spectrum, suggesting that all types of $\mathrm{Ca}$ channels are located at roughly the same distance from secretory sites. By contrast, a "random colocalization" hypothesis cannot account for either the much larger component of strongly coupled secretion (comprising $\sim 97 \%$ of the total secretion at $0.25 \mathrm{~Hz}$ ) (Fig. 4) seen here in calf AC cells or its selective abolition by nisoldipine. With the model elaborated by Klingauf and Neher (1997), we were able to estimate the average distance between facilitation $\mathrm{Ca}$ channels and release sites in calf AC cells using our experimentally determined decay time constant of $3.1 \mathrm{msec}$ for the strongly coupled component (Fig. 6). This analysis yielded a value of $13 \mathrm{~nm}$, indicating an association of molecular dimensions between this type of $\mathrm{Ca}$ channel and the exocytotic apparatus in these cells.

The present data imply that the $\mathrm{Ca}$ channel complement of bovine chromaffin cells changes during development and thus explains several discrepancies that have appeared in the literature. Some studies have described a form of voltage-dependent facilitation of $\mathrm{Ca}$ current in bovine chromaffin cells that apparently is caused by relief of a tonic G-protein-mediated inhibition of non-L-type Ca channels (Doupnik and Pun, 1994; Albillos et al., 1996), a phenomenon well known in neuronal preparations (for review, see Dolphin, 1996). Because these studies were all conducted on AC cells derived from adult cattle, it would not have been possible to detect the facilitation L-type Ca channel, thus negating the claim by some authors that they have "disproved" the existence of the facilitation L-type Ca channel in bovine chromaffin cells (Albillos et al., 1996). The facilitation L-type Ca channel in calf AC cells is regulated, in fact, by a phosphorylation event and not by G-proteins. Voltage-dependent facilitation is blocked in the presence of kinase inhibitors, is augmented by phosphatase inhibitors, and can be prevented by inclusion of the catalytic subunit of protein phosphatase $2 \mathrm{~A}$ in the patch pipette (Artalejo et al., 1992b). Introduction of agents that modify G-protein function into calf $\mathrm{AC}$ cells (GDP $\beta S$ and GTP $\gamma \mathrm{S}$ ) have no effect on the recruitment of facilitation $\mathrm{Ca}$ current (Artalejo et al., 1995; and our unpublished results). Voltage-dependent facilitation of L-type $\mathrm{Ca}$ channels has been seen in a number of neuronal preparations (for review, see Dolphin, 1996). How closely related such channels will be at the molecular level remains to be determined. It is not inherently surprising that cells derived from animals of different ages express different types of $\mathrm{Ca}$ channels. Developmental regulation of $\mathrm{Ca}$ channel expression has been observed in a number of cell types (McCobb et al., 1989; Scholz and Miller, 1995). Moreover, previous studies on AC cells have shown that other responses, such as to nerve growth factor, are strongly developmentally regulated (Naujocks et al., 1982). Because AC cells derived from adult cattle possess a "standard" L-type Ca current (i.e., one not recruited by depolarizing stimuli), it will be interesting to determine whether the facilitation L-type channel is replaced by the 
product of a separate gene or whether some regulatory feature that alters the behavior of the same channel is lost during aging.

Our results suggest that secretion from neuroendocrine cells has a component that approaches the rate of events occurring in nerve terminals. The latency of $\sim 3 \mathrm{msec}$ for the strongly coupled component is the shortest delay reported for a neuroendocrine cell. Because our experiments were all conducted at $24^{\circ} \mathrm{C}$, and it is known that secretion from chromaffin cells is very temperature sensitive (Pihel et al., 1996), it is likely that at $37^{\circ} \mathrm{C}$ strongly coupled secretion could occur in substantially $<3 \mathrm{msec}$. These values are comparable with those found for transmitter release at some nerve terminals using small synaptic vesicles. For example, in Retzius neurons of the leech, release of serotonin from such vesicles exhibited a latency of $4.6 \mathrm{msec}$ (Bruns and Jahn, 1995). In the latter study, the latency of serotonin secretion from large dense-core vesicles was $16 \mathrm{msec}$; however, it was not clear whether this reflected differences in the underlying fusion reactions, distance from $\mathrm{Ca}$ entry sites, or even differences in the rate of release of transmitter from the matrix of the different types of vesicle. Why would calf AC cells possess such a rapid exocytosis mechanism? We speculate that facilitation $\mathrm{Ca}$ channels may be critical to the "fight-or-flight" response. The speed of catecholamine secretion into the bloodstream determines, in part, the rapidity with which the organism can prepare for escape in times of stress. The recruitment of facilitation $\mathrm{Ca}$ channels by repetitive action potentials ensures that they will dominate the secretory response during strong synaptic activation, providing a type of "tuning" mechanism. It is entirely possible that the developmental regulation of L-type $\mathrm{Ca}$ channels described here, namely facilitation channels giving way to standard channels, relates to the strength of the fight-or-flight response in animals of different ages and may have an evolutionary origin. The rapidity of the response in younger animals, still in their reproductive prime, maximizes their chances of escape from danger. As the speed of the response declines in older animals, it may render them more susceptible to predatory cull. If this speculation is correct, then the type of colocalization described here may not be a mere curiosity of calf AC cells. Recent results on mouse chromaffin cells in slice preparations also yielded evidence for "rapid exocytosis" (Moser and Neher, 1997) that was interpreted as support for colocalization, although the type of $\mathrm{Ca}$ channels involved was not defined in that study. Rat (Hollins and Ikeda, 1996) and human (A. Elhamdani and C. R. Artalejo, unpublished results) $\mathrm{AC}$ cells possess facilitation $\mathrm{Ca}$ channels and thus may also exhibit the same type of strong stimulus-secretion coupling described here.

\section{REFERENCES}

Adler EM, Augustine GJ, Duffy SN, Charlton MP (1991) Alien intracellular calcium chelators attenuate neurotransmitter release at the squid giant synapse. J Neurosci 11:1496-1507.

Albillos A, Gandia L, Michelana P, Gilabert J-A, del Valle M, Carbone E, Garcia A (1996) The mechanism of calcium channel facilitation in bovine chromaffin cells. J Physiol (Lond) 494:687-695.

Almers W (1990) Exocytosis. Annu Rev Physiol 52:607-624.

Artalejo CR, Ariano MA, Perlman RL, Fox AP (1990) $D_{1}$ Dopamine receptors activate facilitation $\mathrm{Ca}$ channels in chromaffin cells via a cAMP/protein kinase A mechanism. Nature 348:239-242.

Artalejo CR, Dahmer MK, Perlman RL, Fox AP (1991a) Facilitation of Ca current in bovine chromaffin cells is due to recruitment of a second type of whole-cell current with novel properties. J Physiol (Lond) 432:681-707.

Artalejo CR, Mogul DJ, Perlman RL, Fox AP (1991b) Bovine chromaffin cells exhibit three types of calcium channels: facilitation, induced by large pre-depolarizations or repetitive activity is due to the increased opening probability of a $27 \mathrm{pS}$ channel. J Physiol (Lond) 444:213-240.

Artalejo CR, Perlman RL, Fox AP (1992a) , $\omega$-Conotoxin GVIA blocks a $\mathrm{Ca}^{2+}$ current in bovine chromaffin cells that is not of the "classic" $\mathrm{N}$ type. Neuron 8:85-95.

Artalejo CR, Perlman RL, Fox AP (1992b) Voltage-dependent phosphorylation may recruit $\mathrm{Ca}^{2+}$ current facilitation in chromaffin cells. Nature 358:63-66.

Artalejo CR, Adams ME, Fox AP (1994) Three types of Ca channel trigger secretion with different efficacies in chromaffin cells. Nature 367:72-76.

Artalejo CR, Henley J, McNiven M, Palfrey HC (1995) Rapid endocytosis coupled to exocytosis in adrenal chromaffin cells involves $\mathrm{Ca}^{2+}$, GTP and dynamin but not clathrin. Proc Natl Acad Sci USA 92:8328-8332.

Barrett EF, Stevens CS (1972) The kinetics of transmitter release at the frog neuromuscular junction. J Physiol (Lond) 227:691-708.

Bokvist K, Eliasson L, Ammala C, Renstrom E, Rorsman P (1995) Colocalization of L-type $\mathrm{Ca}$ channels and insulin-containing secretory granules and its significance for the initiation of exocytosis in mouse pancreatic $\beta$-cells. EMBO J 15:50-57.

Bruns D, Jahn R (1995) Real-time measurement of transmitter release from single synaptic vesicles. Nature 37::62-65.

Chow RH, von Ruden L, Neher E (1992) Delay in vesicle fusion revealed by electrochemical monitoring of single secretory events in adrenal chromaffin cells. Nature 356:60-63.

Chow RH, Klingauf J, Neher E (1994) Time course of Ca concentration triggering exocytosis in neuroendocrine cells. Proc Natl Acad Sci USA 91:12765-12769.

Chow RH, Klingauf J, Heinemann C, Zucker RS, Neher E (1996) Mechanisms determining the time course of secretion in neuroendocrine cells. Neuron 16:369-376.

Dolphin, AC (1996) Calcium current facilitation in excitable cells. Trends Neurosci 19:35-43.

Douglas WW, Kanno T, Sampson SR (1967) Influence of the ionic environment on the membrane potential of adrenal chromaffin cells and on the depolarizing effect of acetylcholine. J Physiol (Lond) 191:107-121.

Doupnik CA, Pun RYK (1994) G-protein activation mediates prepulse facilitation of $\mathrm{Ca}$ channel currents in bovine chromaffin cells. J Membr Biol 140:47-56.

Engisch KL, Nowycky MC (1996) Calcium dependence of large densecore vesicle exocytosis evoked by $\mathrm{Ca}$ influx in bovine adrenal chromaffin cells. J Neurosci 16:1359-1369.

Haydon PG, Henderson E, Stanley EF (1994) Localization of individual calcium channels at the release face of a presynaptic nerve terminal. Neuron 13:1275-1280

Hollins B, Ikeda SR (1996) Inward currents underlying action potentials in rat chromaffin cells. J Neurophysiol 76:1195-1211.

Kidokoro Y, Ritchie AK (1980), Chromaffin cell action potentials and their possible role in adrenaline secretion from rat adrenal medulla. Nature 278:63-65.

Klingauf J, Neher E (1997) Modeling buffered Ca diffusion near the membrane: implications for secretion in neuroendocrine cells. Biophys J 72:674-690.

Lando L, Zucker RS (1994) $\mathrm{Ca}^{2+}$ cooperativity in neurosecretion measured using photolabile $\mathrm{Ca}^{2+}$ chelators. J Neurophysiol 72:825-831.

Llinas R, Steinberg IZ, Walton K (1981) Relationship between presynaptic $\mathrm{Ca}$ current and postsynaptic potential in squid giant synapse. Biophys J 33:323-351.

Martin TFJ (1994) The molecular machinery for fast and slow neurosecretion. Curr Opin Neurobiol 4: 626-632.

McCobb DP, Beam KG (1991) Action potential waveform voltage-clamp commands reveal striking differences in calcium entry via low- and high-voltage-activated calcium channels. Neuron 7:119-127.

McCobb DP, Best PM, Beam KG (1989) Development alters the expression of calcium channels in chick motoneurons. Neuron 2:1633-1643.

Moser T, Neher E (1997) Rapid exocytosis in single chromaffin cells recorded from mouse adrenal slices. J Neurosci 17:2314-2323.

Naujocks KW, Korsching S, Rohrer H, Thoenen H (1982) Nerve growth factor-mediated induction of tyrosine hydroxylase and of neurite outgrowth in cultures of bovine adrenal chromaffin cells: dependence on developmental stage. Dev Biol 92:365-379.

Nowycky MC, Pinter MJ (1993) Time courses of calcium-bound buffers following calcium influx in a model cell. Biophys J 64:77-91. 
Pihel K, Travis ER, Borges R, Wightman RM (1996) Exocytotic release from individual granules exhibits similar properties at mast and chromaffin cells. Biophys J 71:1633-1640.

Roberts WM (1994) Localization of calcium signals by a mobile calcium buffer in frog saccular hair cells. J Neurosci 14:3246-3252.

Robitaille R, Adler EM, Charlton MP (1990) Strategic location of Ca channels at transmitter release sites of frog neuromuscular synapses. Neuron 6:773-779.

Sabatini BL, Regehr WG (1996) Timing of neurotransmission at fast synapses in the mammalian brain. Nature 384:170-172.

Scholz KP, Miller RJ (1995) Developmental changes in presynaptic Ca channels coupled to glutamate release in cultured rat hippocampal neurons. J Neurosci 15:4612-4617.

Sheng ZH, Rettig J, Cook T, Catterall WA (1996) Calcium-dependent interaction of $\mathrm{N}$-type $\mathrm{Ca}$ channels with the synaptic core complex. Nature 379:451-454.

Whim MD, Lloyd PE (1989) Frequency-dependent release of peptide cotransmitters from identified cholinergic motor neurons in Aplysia. Proc Natl Acad Sci USA 86:9034-9038.

Wightman RM, Jankowski JA, Kennedy RT, Kawagoe KT, Schroeder TJ, Leszczyszyn DJ, Near JA, Diliberto EJ, Viveros OH (1991) Temporally resolved catecholamine spikes correspond to single vesicle release from individual chromaffin cells. Proc Natl Acad Sci USA 88:10754-10758.

Zhou Z, Misler S (1995) Action potential-induced quantal secretion of catecholamines from rat adrenal chromaffin cells. J Biol Chem 270:3498-3505.

Zhou Z, Misler S (1996) Amperometric detection of quantal secretion from patch-clamped rat pancreatic $\beta$-cells. J Biol Chem 271:270-277.

Zhou Z, Neher E (1993) Mobile and immobile $\mathrm{Ca}^{2+}$ buffers in bovine adrenal chromaffin cells. J Physiol (Lond) 469:245-273.

Zhou Z, Misler S, Chow RH (1996) Rapid fluctuations in transmitter release from single vesicles in bovine adrenal chromaffin cells. Biophys J 70:1543-1552. 